\title{
Evaluating fermentation quality, in vitro digestibility and aerobic stability of a total mixed ration ensiled with different additives on Tibet plateau
}

\author{
Zhihao Dong ${ }^{1}$, Siran Wang ${ }^{1}$, Jie Zhao ${ }^{1}$, Junfeng Li ${ }^{1}$, Qinhua Liu ${ }^{1}$, Yuhong Bao ${ }^{2}$, and Tao Shao ${ }^{1, *}$
}

\footnotetext{
* Corresponding Author: Tao Shao Tel: +86-25-84396356, Fax: +86-025-84396356, E-mail: taoshaolan@163.com

${ }^{1}$ Institute of Ensiling and Processing of Grass, College of Agro-grassland Science, Nanjing Agricultural University, Weigang 1, Nanjing 210095, China

2 Institute of Grassland Science, Tibet Academy of Agricultural and Animal Husbandry Sciences, Lhasa 850000, China

\section{ORCID}

Zhihao Dong

https://orcid.org/0000-0001-6532-4784 Siran Wang

https://orcid.org/0000-0002-1990-550X Jie Zhao

https://orcid.org/0000-0001-5403-9865 Junfeng Li

https://orcid.org/0000-0001-6739-7805 Tao Shao

https://orcid.org/0000-0002-3218-046X
}

Submitted Dec 23, 2019; Revised Jan 28, 2020; Accepted Mar 26, 2020
Objective: To investigate the improvement in utilization efficiency of total mixed ration (TMR) on Tibetan plateau, TMR were ensiled with different additives.

Methods: A total of 150 experimental silos were prepared in a completely randomized design to evaluate the six treatments: i) control (without additive), ii) Lactobacillus buchneri (L. buchneri), iii) acetic acid, iv) propionic acid, v) 1,2-propanediol; and vi) 1-propanol. After 90 days of ensiling, silos were opened for fermentation quality and in vitro analysis, and then subjected to an aerobic stability test for 14 days.

Results: Treating with L. buchneri, acetic acid, 1,2-propanediol and 1-propanol decreased propionic acid contents and yeast number, whereas increased $(\mathrm{p}<0.05) \mathrm{pH}$, acetic acid and ethanol contents in the fermented TMR. Despite increased dry matter (DM) loss in the TMRs treated with 1,2-propanediol and 1-pronanol, additives did not affect ( $\mathrm{p}>0.05)$ all in vitro parameters including gas production at $24 \mathrm{~h}\left(\mathrm{GP}_{24}\right)$, GP rate constant, potential $\mathrm{GP}$, in vitro DM digestibility and in vitro neutral detergent fibre digestibility. All additives improved the aerobic stability of ensiled TMR to different extents. Specially, aerobic stability of the ensiled TMR were substantially improved by L. buchneri, acetic acid, 1,2-propanediol, and 1-propanol, indicated by stable $\mathrm{pH}$ and lactic acid content during the aerobic stability test. Conclusion: L. buchneri, acetic acid, 1,2-propanediol, and 1-propanol had no adverse effect on in vitro digestibility, while ensiling TMR with the additives produced more acetic acid and ethanol, subsequently resulting in improvement of aerobic stability. There is a potential for some fermentation boosting additives to enhance aerobic stability of fermented TMR on Tibetan plateau.

Keywords: Additive; Aerobic Stability; Fermentation Quality; Ensiled Total Mixed Ration; Tibet Plateau

\section{INTRODUCTION}

Fermented total mixed ration (TMR) has attracted attention in Tibet in the past decade because ensiling TMR can reduce daily labor for feed preparation, improve longevity, and ease long-distance transportation compared with regular TMR. Furthermore, a large number of agricultural products, such as hulless barley straw (HBS) and wet hulless-barley distillers' grains (WHDG), are available in Tibet. The locally available HBS or WHDS may improve the characteristics of ensiled TMR and replace traditional TMR ingredients which are limited in supply. Pastoral areas are scarce in Tibet and long-distance transportation of feed ingredients are necessary. During the transportation, ensiled feeds are inevitably exposed to air, which easily leads to aerobic deterioration. Identification of effective ways to improve the aerobic stability of fermented TMR is required in the region.

Various additives have been developed to enhance the aerobic stability of silages. Inoc- 
Table 1. Chemical composition of ingredients used for the formulation of total mixed ration

\begin{tabular}{|c|c|c|c|c|c|}
\hline Items & Hulless barley straw & Tall fescue & Alfalfa & $\begin{array}{l}\text { Wet hulless barley } \\
\text { distillers' grains }\end{array}$ & Concentrate \\
\hline Dry matter (g/kg FW) & 748 & 306 & 269 & 144 & 873 \\
\hline Water-soluble carbohydrates (g/kg DM) & 44.8 & 144 & 85.0 & 56.6 & 103 \\
\hline Neutral detergent fiber (g/kg DM) & 720 & 547 & 358 & 381 & 340 \\
\hline Acid detergent fiber (g/kg DM) & 457 & 248 & 260 & 106 & 151 \\
\hline Ether extract (g/kg DM) & 53.9 & 69.7 & 66.8 & 136 & 59.0 \\
\hline Buffering capacity (mEq/kg DM) & 44.0 & 205 & 368 & 126 & 171 \\
\hline
\end{tabular}

FW, fresh weight; DM, dry matter; mEq, milligram equivalent.

ulation with Lactobacillus buchneri (L. buchneri) is effective for enhancing the aerobic stability of silages [1]. Short-chain fatty acids, such as acetic and propionic acids, are able to suppress the growth of yeast and aerobic microorganisms, and also are commonly used as additives to prevent aerobic deterioration of silages [2]. However, effectiveness of an additive on fermentation quality and aerobic stability of silage varies depending on the materials to be ensiled. Studies on evaluating the effectiveness of the additives on locally produced TMR on Tibetan plateau are limited. Additionally, it has been reported that L. buchneri improves aerobic stability by fermenting lactic acid to acetic acid and 1,2-propanediol [3]. Despite acetic acid being generally considered as the main active ingredient responsible for the increased aerobic stability of L. buchneri-inoculated silage, some evidence suggests that accumulations of 1,2-propanediol and 1-propanol during fermentation may also be involved in the resistance to aerobic deterioration $[4,5]$. To our knowledge, previous studies focused exclusively on the evaluation of acetic and propionic acids, with little attention being paid to these alcohols.

The objective of this study was to evaluate the effects of L. buchneri and two short-chain fatty acids as well as two alcohols on the fermentation quality, in vitro digestibility and aerobic stability of an ensiled TMR prepared in Tibet.

\section{MATERIALS AND METHODS}

\section{Total mixed ration silage preparation}

Alfalfa (Medicago sativa L.) and tall fescue (Festuca arundinacea Schreb.) were cultivated in the experimental field of Rikaze Grassland Station ( $29^{\circ} 16^{\prime}$ latitude N, $88^{\circ}$ 53'longitude E, 3,836 $\mathrm{m}$ above sea level, Tibet, China). The HBS was the residue remaining after harvesting grain. Alfalfa was harvested at $75 \%$ bloom and tall fescue was harvested at the boot stage. The forages and HBS were chopped to the length of 2 to $3 \mathrm{~cm}$ with a manual forage chopper. The WHDG was obtained from a private barley wine processing company at
Rikaze, and the mixed concentrates $(7.5 \%$ crack corn, $20 \%$ rape cake meal, $20 \%$ cotton seed, $27.5 \%$ distillers dried grains with soluble, $20 \%$ wheat bran, $5 \%$ vitamin-mineral) were obtained from a private small-scale dairy farm in Rikaze, Tibet, China. TMRs ( $640 \mathrm{~g}$ ) were ensiled using a plastic laboratory silo (1 L capacity). The chemical compositions of all used materials are shown in Table 1, and ingredients and chemical compositions of TMR are shown in Table 2. A total of 150 experimental silos ( 6 treatments $\times 5$ time points $\times 5$ replicates per treatment) were prepared in a completely randomized design to evaluate the following treatments: i) control (without additive), ii) L. buchneri, iii) acetic acid, iv) propionic acid, v) 1,2-propanediol, and vi) 1-propanol. The L. buchneri was supplied by Institute of Forage Ensiling and Processing of Nanjing Agricultural University and ap-

Table 2. Ingredients and chemical composition of total mixed rations without additives before ensiling

\begin{tabular}{|c|c|}
\hline Items & Total mixed ration \\
\hline \multicolumn{2}{|l|}{ Ingredients of feedstuff (g/kg DM) } \\
\hline Hulless barley straw & 160 \\
\hline Tall fescue & 60 \\
\hline Alfalfa & 170 \\
\hline Wet hulless barley distillers' grains & 60 \\
\hline Concentrate & 550 \\
\hline \multicolumn{2}{|l|}{ Chemical composition } \\
\hline DM (g/kg FW) & 485 \\
\hline Crude protein (g/kg DM) & 147 \\
\hline Water-soluble carbohydrates (g/kg DM) & 90.5 \\
\hline Neutral detergent fiber (g/kg DM) & 418 \\
\hline Acid detergent fiber (g/kg DM) & 221 \\
\hline Ash (g/kg DM) & 93.9 \\
\hline Ether extract (g/kg DM) & 64.8 \\
\hline Buffering capacity (mEq/kg DM) & 184 \\
\hline \multicolumn{2}{|l|}{ Microbial composition } \\
\hline Lactic acid bacteria $\left(\log _{10} \mathrm{cfu} / \mathrm{g} F W\right)$ & 5.37 \\
\hline Aerobic bacteria ( $\left.\log _{10} \mathrm{cfu} / \mathrm{g} \mathrm{FW}\right)$ & 6.44 \\
\hline Yeast $\left(\log _{10} \mathrm{cfu} / \mathrm{g}\right.$ FW) & 5.21 \\
\hline
\end{tabular}

DM, dry matter; FW, fresh weight; $\mathrm{mEq}$, milligram equivalent; cfu, colony-forming units. 
plied at $1 \times 10^{6}$ colony-forming units (cfu)/g based on fresh weight (FW) [6]. The application rates of acetic and propionic acids were $0.3 \% \mathrm{FW}$ (equals to $6.2 \mathrm{~g} / \mathrm{kg}$ dry matter [DM]) [6]. The 1-propanol and 1,2-propanediol were applied at $0.5 \% \mathrm{FW}$. All chemicals used were of analytical grade. The prepared silos were stored at ambient temperature, opened after 90 days and then subjected to an aerobic stability test for 14 days.

\section{Chemical and microbial analysis}

Fresh forages, pre-ensiled TMR and fermented TMR were analyzed for chemical and microbiological compositions. Approximately $200 \mathrm{~g}$ of sample was oven-dried at $60^{\circ} \mathrm{C}$ for $48 \mathrm{~h}$ to determine DM content and then ground to pass 1-mm screen with laboratory knife mills (FW100, Taisite Instrument Co., Ltd., Tianjin, China) for other chemical composition analysis. Total nitrogen (TN, 978.04), ether extract (EE, 920.39), and crude ash (Ash, 942.05) were measured according to the methods of Association of Official Analytical Chemists [7]. Crude protein $(\mathrm{CP})$ was calculated as $\mathrm{TN} \times 6.25$. Water soluble carbohydrates (WSC) was determined by colorimetric after reaction with anthrone reagent [2]. The contents of neutral detergent fibre (aNDFom) and acid detergent fibre (ADFom) were measured by the procedures of Van Soest et al [8], the heat stable amylase and sodium sulphite were used for NDF procedure.

For microbiological composition analysis, 10 grams of sample was blended with $90 \mathrm{~mL}$ of sterilized water, and serially diluted in sterilized water. The lactic acid bacteria (LAB) was counted on de Man, Rogosa, and Sharpe agar medium, incubated in an anaerobic incubator at $30^{\circ} \mathrm{C}$ for 2 days. Yeasts and aerobic bacteria were enumerated on potato dextrose agar (Sinopharm Chemical Reagent Co., Ltd., Shanghai, China) and nutrient agar (Shanghai Sincere Biochemical Technology Co., Ltd., Shanghai, China) under aerobic conditions.

About 35 grams of sample was blended with $60 \mathrm{~mL}$ distilled water and macerated for $24 \mathrm{~h}$ at $4^{\circ} \mathrm{C}$. The extract was filtered through 2 layers of cheesecloth and a filter paper (Xinhua Co, Ltd., Hangzhou, China). The filtrate was used for $\mathrm{pH}$, organic acids and ammonia nitrogen $\left(\mathrm{NH}_{3}-\mathrm{N}\right)$ determinations. The $\mathrm{pH}$ was measured with a HANNA HI 2221 pH meter (Hanna Instruments Italia Srl, Villafranca Padovana, Italy). The $\mathrm{NH}_{3}-\mathrm{N}$ was determined using the phenolhypochlorite reaction method [9]. Buffering capacity was determined according to the method of Chen et al [10]. The organic acids (including lactic, acetic, and propionic acids) and alcohols (including ethanol, 1,2-propanediol and 1-propanol) were quantified using an Agilent 1260 HPLC system equipped with a refractive index detector (Carbomix H-NP5 column, $2.5 \mathrm{mM} \mathrm{H}_{2} \mathrm{SO}_{4}, 0.5 \mathrm{~mL} / \mathrm{min}$ ).

\section{In vitro incubation and dry matter degradability measurements}

In vitro fermentation was conducted in serum bottles following the method of Contreras-Govea et al [11] with some modifications. Briefly, approximately $1 \mathrm{~g}$ of ground sample was placed in $130-\mathrm{mL}$ serum bottles. The rumen fluid was obtained through a rumen fistula before morning feeding from four dry Boer goats fed with diet consisting of $6 \%$ alfalfa, $59 \%$ guinea grass, and $35 \%$ concentrate at 1.3 times of the maintenance level. Rumen fluid was filtered through 4 layers of gauze and mixed in the ratio of 1:2 $(\mathrm{v} / \mathrm{v})$ with buffer, and $60 \mathrm{~mL}$ of the mixture was transferred into each serum bottle. Each serum bottle was flushed with $\mathrm{CO}_{2}$ and kept in a water bath at $39^{\circ} \mathrm{C}$, after being capped with a butyl rubber stopper and sealed with an aluminum crimp. Gas production was measured at $4,8,12,24,48$, and $72 \mathrm{~h}$ using a pressure transducer technique and corrected with blank bottles. After $72 \mathrm{~h}$ of incubation, undigested solids were precipitated by centrifugation at $1,000 \mathrm{~g}$ for $10 \mathrm{~min}$ at room temperature, dried in an aerated oven at $65^{\circ} \mathrm{C}$ for $48 \mathrm{~h}$ and then assayed for DM and aNDF. The in vitro digestibility of DM (IVDMD) and NDF (IVNDFD) were calculated based on the differences in their respective weight before and after incubation.

Cumulative gas production (GP) data were fitted to the exponential equation: $y=b\left(1-e^{-c t}\right)$, where $y$ is the volume of gas produced at time $t, b$ is the GP from the insoluble fraction $(\mathrm{mL}), \mathrm{c}$ is the GP rate constant, $\mathrm{t}$ is the incubation time (h).

\section{Aerobic stability test}

After 90 days of ensiling, fermented TMR from each silo was taken out, fully mixed and loosely placed into a bigger $15 \mathrm{~L}$ open-top and sterile polyethylene bottle. Each bottle was covered with a double layer of gauze and stored at ambient temperature $\left(24^{\circ} \mathrm{C}\right.$ to $\left.27^{\circ} \mathrm{C}\right)$. During the test, TMR were sampled for $\mathrm{pH}$, organic acids, $\mathrm{NH}_{3}-\mathrm{N}$, WSC, and microbes count analyses at $0,3,6,9$, and 14 days. Aerobic stability is defined as a rise in $\mathrm{pH}$ value of TMR by 0.5 unit above the initial $\mathrm{pH}$ value at silos opening [12].

\section{Statistical analyses}

Analysis of variance (ANOVA) was performed using the general linear model procedure of SAS rev. 9.2. The data related to fermentation variables were subjected to one-way ANOVA, with fixed effect of treatments. While data related to chemical and microbial composition during aerobic exposure were analyzed using the following model: $Y_{i j}=\mu+S_{i}+$ $A_{j}+S_{i} \times A_{j}+\mathcal{E}$, where: $Y_{i j}=$ the response variable; $S_{i}=$ treatment; $A_{j}=$ aerobic exposure; $S_{i} \times A_{j}=$ treatment $\times$ aerobic exposure; $\varepsilon=$ random errors. Duncan's multiple range test was used to separate means when significant effects $(\mathrm{p}<0.05)$ were detected. 


\section{RESULTS}

Characteristics of feed ingredients and total mixed ration before ensiling

As shown in Table 1, two roughages contained similar ADF, ash, and EE. Compared with tall fescue, alfalfa was lower in DM, WSC, and NDF contents, while higher in CP and buffering capacity. The chemical and microbial compositions of the TMR before ensiling are presented in Table 2. The DM, NDF, CP, and WSC contents of TMR were 485, 418, 221, and $90.5 \mathrm{~g} / \mathrm{kg} \mathrm{DM}$, respectively. The LAB, aerobic bacteria and yeast counts were $5.37,6.44$, and $5.21 \log _{10} \mathrm{cfu} / \mathrm{g} \mathrm{FW}$, respectively.

Fermentation quality of ensiled total mixed ration The fermentation quality and microbial composition of TMR after 90 days of ensiling are given in Table 3 . Additives affected all fermentation parameters $(\mathrm{p}<0.05)$, except for butyric acid contents and LAB number. Treating L. buchneri, acetic acid decreased propionic acid contents, whereas increased $(\mathrm{p}<$ $0.05) \mathrm{pH}$, acetic acid and ethanol contents. Adding 1,2-propanediol and 1-propanol decreased $(\mathrm{p}<0.05)$ lactic acid and propionic acid contents, whereas increased $\mathrm{pH}$, acetic acid, ethanol and $\mathrm{NH}_{3}-\mathrm{N}$ contents. The 1-propanol and 1,2-propanediol were only accumulated greatly in their respectively treated TMR. Addition of acetic acid reduced $(\mathrm{p}<0.05)$ the aerobic bacteria counts. Compared with other TMR, the numbers of yeasts were much lower $(\mathrm{p}<0.05)$ in TMR ensiled with L. buchneri, acetic acid, 1,2-propanediol, and 1-propanol.

\section{Chemical compositions and in vitro degradability of ensiled total mixed ration}

The chemical compositions of ensiled TMR after 90 days of ensiling is shown in Table 4. With respect to chemical compositions, only DM was influenced by the additives $(\mathrm{p}<0.05)$. Compared with control, TMR ensiled with 1,2-propanediol and 1-propanol showed lower $(\mathrm{p}<0.05) \mathrm{DM}$ contents and higher $(\mathrm{p}<0.05) \mathrm{DM}$ loss. The measured or estimated in vitro parameters are presented in Table 5 and Figure 1. The potential GP ranged from 158 to $200 \mathrm{~mL} / \mathrm{g}$ DM. Additives did not affect in vitro parameters including $\mathrm{GP}_{24}$, GP rate constant, potential GP, IVDMD, and IVNDFD.

\section{Aerobic stability of ensiled total mixed ration}

The changes in fermentative characteristics and microbial compositions of ensiled TMR during aerobic exposure are given in Table 6 and 7, respectively. The control began to spoil after 6 days of aerobic exposure, with rises in $\mathrm{pH}$ and declines in lactic acid contents. All additives improved the aerobic stability of ensiled TMR to different extents. Of the additives, L. buchneri, acetic acid, 1,2-propanediol, and 1-propanol had superior abilities to propionic acid at improving aerobic stability, indicated by stable $\mathrm{pH}$ and lactic acid content. Throughout the aerobic stability test, acetic acid, and ethanol contents were always greater $(\mathrm{p}<0.05)$ in L. buchneri, acetic acid, 1,2-propanediol, and 1-propanol-treated TMR relative to other TMR. Table 7 shows the changes in chemical compositions of ensiled TMR during aerobic exposure. The DM, WSC, and $\mathrm{NH}_{3}-\mathrm{N}$ contents fluctuated during the test period and did not differ among the TMRs at most intervals of the aerobic stability test. The changes in microbial

Table 3. Fermentation parameters and microbial compositions of total mixed ration after 90 days of ensiling

\begin{tabular}{|c|c|c|c|c|c|c|c|c|}
\hline \multirow{2}{*}{ Items } & \multicolumn{6}{|c|}{ Treatments $^{1)}$} & \multirow{2}{*}{ SEM } & \multirow{2}{*}{ p-value } \\
\hline & Control & B & A & $\mathbf{P}$ & $\mathbf{E}$ & $\mathbf{F}$ & & \\
\hline \multicolumn{9}{|l|}{ Fermentation parameters } \\
\hline $\mathrm{pH}$ & $4.27^{A}$ & $4.53^{B C}$ & $4.45^{\mathrm{B}}$ & $4.35^{\mathrm{A}}$ & $4.59^{C}$ & $4.58^{C}$ & 0.013 & $<0.001$ \\
\hline Lactic acid (g/kg DM) & $74.3^{\mathrm{B}}$ & $65.6^{\mathrm{AB}}$ & $67.8^{\mathrm{AB}}$ & $72.6^{\mathrm{B}}$ & $62.0^{A}$ & $60.0^{A}$ & 1.073 & 0.013 \\
\hline Acetic acid (g/kg DM) & $21.0^{A}$ & $38.0^{\mathrm{B}}$ & $37.0^{\mathrm{B}}$ & $21.0^{A}$ & $34.5^{\mathrm{B}}$ & $40.1^{B}$ & 0.528 & $<0.001$ \\
\hline Lactic acid/acetic acid & $3.54^{\mathrm{B}}$ & $1.73^{\mathrm{A}}$ & $1.83^{\mathrm{A}}$ & $3.46^{\mathrm{B}}$ & $1.80^{\mathrm{A}}$ & $1.50^{\mathrm{A}}$ & 0.069 & $<0.001$ \\
\hline Propionic acid (g/kg DM) & $6.30^{\mathrm{D}}$ & $1.50^{\mathrm{B}}$ & $0.00^{A}$ & $7.40^{\mathrm{D}}$ & $4.19^{C}$ & $3.10^{C}$ & 0.112 & $<0.001$ \\
\hline Ethanol (g/kg DM) & $22.4^{\mathrm{A}}$ & $41.8^{\mathrm{ABC}}$ & $42.86^{\mathrm{ABC}}$ & $29.6^{A}$ & $55.2^{\mathrm{BC}}$ & $59.2^{C}$ & 3.796 & 0.009 \\
\hline 1,2-propanediol (g/kg DM) & $0.00^{\mathrm{A}}$ & $0.00^{A}$ & $0.00^{A}$ & $0.00^{A}$ & $5.45^{\mathrm{B}}$ & $0.12^{A}$ & 0.008 & $<0.001$ \\
\hline 1-propanol (g/kg DM) & $0.00^{A}$ & $0.00^{A}$ & $0.00^{A}$ & $0.00^{\mathrm{A}}$ & $0.00^{A}$ & $4.87^{B}$ & 0.005 & 0.012 \\
\hline Butyric acid (g/kg DM) & 0.00 & 0.00 & 0.00 & 0.00 & 0.00 & 0.00 & 0.00 & - \\
\hline Ammonia nitrogen (g/kg TN) & $76.7^{\mathrm{AB}}$ & $81.7^{\mathrm{ABC}}$ & $74.4^{\mathrm{AB}}$ & $70.7^{\mathrm{A}}$ & $90.1^{c}$ & $85.3^{\mathrm{BC}}$ & 2.094 & 0.040 \\
\hline \multicolumn{9}{|l|}{ Microbial compositions } \\
\hline Lactic acid bacteria & 7.53 & 6.86 & 6.83 & 7.52 & 7.6 & 7.34 & 0.115 & 0.256 \\
\hline Aerobic bacteria & $6.66^{\mathrm{B}}$ & $6.07^{B}$ & $5.17^{\mathrm{A}}$ & $6.78^{\mathrm{B}}$ & $6.79^{B}$ & $6.61^{B}$ & 0.077 & $<0.001$ \\
\hline Yeast & $5.55^{\mathrm{C}}$ & $1.40^{\mathrm{AB}}$ & $1.77^{\mathrm{AB}}$ & $5.55^{\mathrm{C}}$ & $2.94^{\mathrm{BC}}$ & $0.00^{A}$ & 0.354 & 0.003 \\
\hline
\end{tabular}

SEM, standard error of means; DM, dry matter; TN, total nitrogen.

1) B, L. buchneri; A, acetic acid; P, propionic acid; E, 1,2-propanediol; F, 1-propanol.

$A-D$ Means in the same row with different superscripts differ $(p<0.05)$. 
Table 4. Chemical compositions of the total mixed ration after 90 days of ensiling

\begin{tabular}{|c|c|c|c|c|c|c|c|c|}
\hline \multirow{2}{*}{ Items } & \multicolumn{6}{|c|}{ Treatments $^{1)}$} & \multirow{2}{*}{ SEM } & \multirow{2}{*}{ p-value } \\
\hline & Control & B & A & $\mathbf{P}$ & E & $\mathbf{F}$ & & \\
\hline Dry matter (g/kg FW) & $477^{A}$ & $466^{B}$ & $480^{A}$ & $482^{A}$ & $451^{B}$ & $463^{B}$ & 3.386 & 0.019 \\
\hline Dry matter loss & $4.02^{A}$ & $6.24^{B}$ & $3.42^{\mathrm{A}}$ & $3.02^{A}$ & $9.26^{\mathrm{B}}$ & $6.84^{\mathrm{B}}$ & 0.012 & 0.023 \\
\hline Crude protein (g/kg DM) & 159 & 155 & 154 & 168 & 160 & 156 & 1.649 & 0.234 \\
\hline Water-soluble carbohydrates (g/kg DM) & 16.5 & 18.3 & 17.7 & 19.5 & 13.5 & 15.8 & 1.012 & 0.627 \\
\hline Neutral detergent fiber (g/kg DM) & 412 & 408 & 386 & 405 & 441 & 397 & 9.878 & 0.765 \\
\hline Acid detergent fiber (g/kg DM) & 182 & 212 & 225 & 233 & 240 & 230 & 11.381 & 0.792 \\
\hline Ash (g/kg DM) & 87.8 & 91.8 & 102 & 97.9 & 123 & 105 & 3.831 & 0.097 \\
\hline Ether extract (g/kg DM) & 76.5 & 73.9 & 80.6 & 85.4 & 91.1 & 89.4 & 2.045 & 0.068 \\
\hline
\end{tabular}

SEM, standard error of means; FW, fresh weight; DM, dry matter.

1) B, L. buchneri; A, acetic acid; P, propionic acid; E, 1,2-propanediol; F, 1-propanol.

${ }^{A B}$ Means in the same row with different superscripts differ $(p<0.05)$.

Table 5. In vitro degradability and gas production kinetics of total mixed ration after 90 days of ensiling

\begin{tabular}{|c|c|c|c|c|c|c|c|c|}
\hline \multirow{2}{*}{ Items } & \multicolumn{6}{|c|}{ Treatments $^{1)}$} & \multirow{2}{*}{ SEM } & \multirow{2}{*}{ p-value } \\
\hline & Control & B & A & $\mathbf{P}$ & $E$ & $\mathbf{F}$ & & \\
\hline \multicolumn{9}{|l|}{ Degradability } \\
\hline IVDMD & 269 & 297 & 271 & 294 & 305 & 315 & 5.939 & 0.123 \\
\hline IVNDFD & 145 & 147 & 146 & 152 & 167 & 169 & 2.413 & 0.064 \\
\hline \multicolumn{9}{|c|}{ In vitro gas production kinetics } \\
\hline $\mathrm{GP}_{24}(\mathrm{~mL})$ & 110 & 96.4 & 111 & 110 & 123 & 126 & 6.292 & 0.066 \\
\hline Rate of GP (mL/h) & 0.047 & 0.039 & 0.051 & 0.058 & 0.047 & 0.042 & 0.003 & 0.210 \\
\hline Potential GP (mL) & 173 & 175 & 162 & 158 & 161 & 200 & 6.943 & 0.137 \\
\hline
\end{tabular}

$\mathrm{SEM}$, standard error of means; DM, dry matter; IVDMD, in vitro degradability of DM; IVNDFD, in vitro degradability of neutral detergent fibre; $\mathrm{GP}_{24}$, gas pro- $^{-}$ duction at $24 \mathrm{~h}$.

1) B, L. buchneri; A, acetic acid; P, propionic acid; E, 1,2-propanediol; F, 1-propanol.

composition of ensiled TMR during aerobic exposure are displayed in Table 8. TMR ensiled with L. buchneri, acetic acid, 1,2-propanediol, and 1-propanol showed numerically, or significantly lower yeast and aerobic bacteria counts than other TMR during the aerobic exposure.

\section{DISCUSSION}

\section{Additives on fermentative parameters}

The fermentation quality of silage depends on the chemical and microbial properties of the material to be ensiled. To

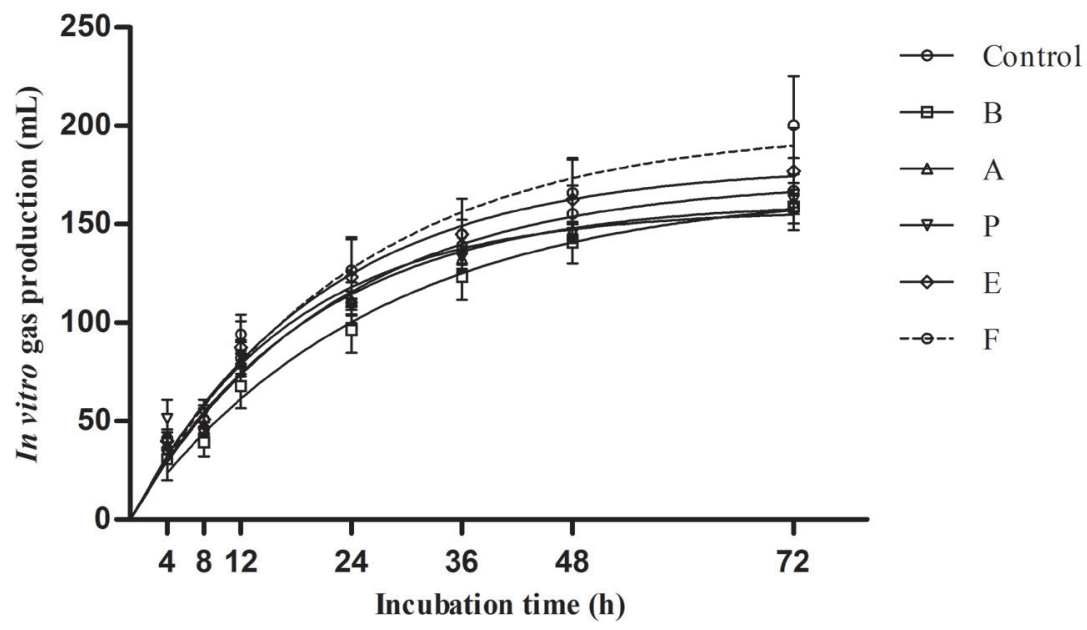

Figure 1. Gas production kinetics ( $\mathrm{mL} / \mathrm{g}$ dry matter) from in vitro fermentation of fermented total mixed ration for $72 \mathrm{~h}$ ( $\mathrm{n}=5$, bars indicate standard error of the means). B, L. buchneri; A, acetic acid; P, propionic acid; E, 1,2-propanediol; F, 1-propanol. Gas production data were fitted to the exponential model: $y=b\left(1-e^{-c t}\right)$; the parameters $b$ and $c$ were estimated by an iterative least squares procedure using the NLIN procedures of SAS. There were no significant differences in gas production between the treatments during incubation. 
Table 6. Changes in fermentative characteristics of fermented total mixed ration during aerobic exposure

\begin{tabular}{|c|c|c|c|c|c|c|c|c|c|c|}
\hline \multirow{2}{*}{ Items } & \multirow{2}{*}{ Treatments $^{1)}$} & \multicolumn{5}{|c|}{ Days of exposure (d) } & \multirow{2}{*}{ SEM } & \multicolumn{3}{|c|}{ p-value ${ }^{2)}$} \\
\hline & & 0 & 3 & 6 & 9 & 14 & & $\mathbf{T}$ & D & $T \times D$ \\
\hline \multirow[t]{4}{*}{$\mathrm{pH}$} & Control & $4.27^{\mathrm{Aa}}$ & $4.36^{\mathrm{Aab}}$ & $4.39^{\mathrm{Ab}}$ & $4.87^{\mathrm{Cc}}$ & $5.95^{\mathrm{Cd}}$ & 0.008 & $<0.001$ & $<0.001$ & $<0.001$ \\
\hline & $A$ & $4.45^{\mathrm{BC}}$ & $4.41^{\mathrm{A}}$ & $4.42^{\mathrm{A}}$ & $4.45^{\mathrm{A}}$ & $4.45^{\mathrm{A}}$ & & & & \\
\hline & $P$ & $4.35^{\mathrm{ABa}}$ & $4.36^{\mathrm{Aa}}$ & $4.36^{\mathrm{Aa}}$ & $4.49^{\mathrm{Ab}}$ & $5.16^{\mathrm{Bc}}$ & & & & \\
\hline & $E$ & $4.59^{C}$ & $4.64^{C}$ & $4.61^{\mathrm{B}}$ & $4.64^{\mathrm{BC}}$ & $4.62^{\mathrm{AB}}$ & & & & \\
\hline \multirow{6}{*}{$\begin{array}{l}\text { Lactic acid } \\
\qquad(\mathrm{g} / \mathrm{kg} \mathrm{DM})\end{array}$} & Control & $74.3^{\mathrm{BC}}$ & $90.0^{B C}$ & $36.4^{\mathrm{Ab}}$ & $38.5^{\mathrm{Ab}}$ & $25.0^{\mathrm{Aa}}$ & 0.914 & $<0.001$ & $<0.001$ & 0.001 \\
\hline & B & $65.6^{\mathrm{ABb}}$ & $69.0^{\mathrm{Ab}}$ & $45.9^{\mathrm{Ba}}$ & $56.1^{\mathrm{Bab}}$ & $55.8^{\mathrm{Bab}}$ & & & & \\
\hline & A & $67.8^{\mathrm{ABb}}$ & $72.3^{\mathrm{BCb}}$ & $42.6^{\mathrm{Ba}}$ & $79.2^{\mathrm{cb}}$ & $61.5^{\mathrm{Bab}}$ & & & & \\
\hline & $P$ & $72.6^{\mathrm{BC}}$ & $77.6^{\mathrm{BCc}}$ & $52.5^{\mathrm{Bb}}$ & $38.5^{\text {Aab }}$ & $30.2^{\mathrm{Aa}}$ & & & & \\
\hline & $E$ & $62.2^{\mathrm{ABb}}$ & $58.8^{\mathrm{Aab}}$ & $48.8^{\mathrm{Ba}}$ & $49.0^{\mathrm{Ba}}$ & $59.4^{\mathrm{Bab}}$ & & & & \\
\hline & F & $59.9^{\mathrm{Aab}}$ & $61.7^{\mathrm{Aab}}$ & $62.1^{\mathrm{cb}}$ & $52.4^{\mathrm{Ba}}$ & $53.0^{\mathrm{Ba}}$ & & & & \\
\hline \multirow{3}{*}{$\begin{array}{l}\text { Acetic acid } \\
\quad(\mathrm{g} / \mathrm{kg} \mathrm{DM})\end{array}$} & $P$ & $20.7^{A}$ & $16.2^{\mathrm{A}}$ & $12.8^{\mathrm{AB}}$ & $21.0^{\mathrm{AB}}$ & $9.95^{\mathrm{A}}$ & & & & \\
\hline & $E$ & $34.5^{\mathrm{Bb}}$ & $26.2^{\mathrm{ABa}}$ & $27.1^{\mathrm{Ca}}$ & $29.4^{\mathrm{ABab}}$ & $28.7^{\mathrm{Ba}}$ & & & & \\
\hline & $\mathrm{F}$ & $40.1^{\mathrm{B}}$ & $32.6^{\mathrm{B}}$ & $41.9^{D}$ & $36.1^{\mathrm{B}}$ & $34.3^{B}$ & & & & \\
\hline \multirow{6}{*}{$\begin{array}{l}\text { Propionic acid } \\
\quad(\mathrm{g} / \mathrm{kg} \mathrm{DM})\end{array}$} & Control & $6.27^{\mathrm{Dc}}$ & $0.03^{\mathrm{Aa}}$ & $2.50^{\mathrm{Ab}}$ & $2.85^{\mathrm{Ab}}$ & $2.48^{\mathrm{Ab}}$ & 0.078 & $<0.001$ & $<0.001$ & $<0.001$ \\
\hline & B & $1.53^{\mathrm{Ba}}$ & $1.22^{\mathrm{ABa}}$ & $2.99^{\mathrm{Ab}}$ & $3.72^{\mathrm{Ac}}$ & $3.81^{\mathrm{ABC}}$ & & & & \\
\hline & A & $0.00^{\mathrm{Aa}}$ & $0.01^{\mathrm{Aa}}$ & $2.85^{\mathrm{Ab}}$ & $3.81^{\mathrm{AC}}$ & $3.43^{\mathrm{ABbc}}$ & & & & \\
\hline & $P$ & $7.36^{\mathrm{Dab}}$ & $5.57^{\mathrm{Ca}}$ & $5.02^{\mathrm{Ba}}$ & $9.22^{\mathrm{Bc}}$ & $7.99^{\mathrm{Db}}$ & & & & \\
\hline & $E$ & $4.19^{\mathrm{Cab}}$ & $2.67^{\mathrm{Ba}}$ & $5.27^{\mathrm{Bb}}$ & $5.46^{\mathrm{Ab}}$ & $5.56^{\mathrm{Cb}}$ & & & & \\
\hline & $\mathrm{F}$ & $3.11^{\mathrm{Ca}}$ & $2.55^{\mathrm{Ba}}$ & $5.04^{\mathrm{Bb}}$ & $4.47^{\mathrm{Ab}}$ & $4.46^{\mathrm{BCb}}$ & & & & \\
\hline \multirow{2}{*}{$\begin{array}{l}\text { Ethanol } \\
\qquad(\mathrm{g} / \mathrm{kg} \mathrm{DM})\end{array}$} & Control & $22.4^{A}$ & $11.1^{\mathrm{A}}$ & $6.08^{A}$ & $1.03^{\mathrm{A}}$ & $0.00^{A}$ & 0.614 & $<0.001$ & $<0.001$ & 0.068 \\
\hline & B & $41.8^{\mathrm{ABC}}$ & $15.1^{\mathrm{ABab}}$ & $12.6^{\mathrm{ABa}}$ & $18.5^{\mathrm{BCb}}$ & $11.5^{\mathrm{Ba}}$ & & & & \\
\hline
\end{tabular}

SEM, standard error of means; DM, dry matter.

1) B, L. buchneri; A, acetic acid; P, propionic acid; E,1,2-propanediol; F, 1-propanol.

2) $T$, treatment; $D$, ensiling day; $T \times D$, interaction between treatment and ensiling day.

${ }^{A-D}$ Means in the same column with different capital letter differed $(p<0.05)$.

a-d Means in the same row with different lowercase differed $(p<0.05)$.

ensure satisfactory silage quality (i.e., extensive lactic fermentation and high recovery of DM and energy), a feedstuff must have adequate WSC content ( $>60 \mathrm{~g} / \mathrm{kg} \mathrm{DM})$ and population of LAB ( $\left.>5.00 \log _{10} \mathrm{cfu} / \mathrm{g} \mathrm{FW}\right)$ as well as a proper DM (300 to $400 \mathrm{~g} / \mathrm{kg} \mathrm{DM}$ ) [13]. These criteria were almost met in the TMR at the time of ensiling, despite the DM being slightly higher than the normal. After 90 days of ensiling, the butyric acid was undetected and lactic acid was dominant among the fermentation products in all ensiled TMRs (Table 3). Treating with L. buchneri and acetic acid increased $\mathrm{pH}$, acetic acid, and ethanol production in the TMRs. $L$. buchneri is well known as a heterofermentative LAB species. Altered fermentation in L. buchneri-inoculated silage might be attributed to the increased dominance of L. buchneri in epiphytic microflora that shifted the metabolism to a more heterofermentative process, while that in acetic acid-treated silage might be related to the depression of homofermentative LAB species considering that heterofermentative $\mathrm{LAB}$ are more tolerant to acetic acid than homofermentative LAB [14]. Similarly, Ren et al [15] also found that addition of acetic acid weakened the intensity of lactic fermentation and lowered the ratio of lactic to total organic acids in silages prepared with dried corn stover and cabbage waste. Interestingly, it was observed that adding 1,2-propanediol and 1-propanol also increased the $\mathrm{pH}$, acetic acid and ethanol concentrations in the ensiled TMR. The effects of 1,2-propanediol and 1-propanol addition on fermentation have been rarely reported in the literature. However, Mukdsi et al [16] reported that some lactobacilli are capable of synthesizing esters with lactic acid and alcohol as the precursors. A possible explanation might be esterification of lactic acid and the alcohol which slowed the $\mathrm{pH}$ decline and increased 
Table 7. Changes in chemical compositions of fermented total mixed ration during aerobic exposure

\begin{tabular}{|c|c|c|c|c|c|c|c|c|c|c|}
\hline \multirow{2}{*}{ Items } & \multirow{2}{*}{ Treatments ${ }^{1)}$} & \multicolumn{5}{|c|}{ Days of exposure (d) } & \multirow{2}{*}{ SEM } & \multicolumn{3}{|c|}{ p-value ${ }^{2)}$} \\
\hline & & 0 & 3 & 6 & 9 & 14 & & $\mathrm{~T}$ & D & $T \times D$ \\
\hline \multirow[t]{6}{*}{$\mathrm{DM}$ (g/kg FW) } & Control & $477^{\text {Aa }}$ & $524^{b}$ & $531^{b}$ & $538^{b}$ & $496^{a}$ & 1.102 & 0.004 & $<0.001$ & 0.137 \\
\hline & B & $466^{\mathrm{Ba}}$ & $531^{\mathrm{c}}$ & $520^{\mathrm{bc}}$ & $530^{c}$ & $506^{b}$ & & & & \\
\hline & A & $480^{\mathrm{Aa}}$ & $525^{\mathrm{bc}}$ & $526^{\mathrm{bc}}$ & $544^{c}$ & $501^{\mathrm{ab}}$ & & & & \\
\hline & $P$ & $482^{\mathrm{Aa}}$ & $535^{\mathrm{ab}}$ & $534^{\mathrm{ab}}$ & $538^{c}$ & $509^{a b}$ & & & & \\
\hline & E & $451^{\mathrm{Ba}}$ & $529^{c}$ & $530^{c}$ & $521^{\mathrm{bc}}$ & $489^{b}$ & & & & \\
\hline & $\mathrm{F}$ & $463^{\mathrm{Ba}}$ & $532^{b}$ & $532^{b}$ & $537^{b}$ & $483^{a}$ & & & & \\
\hline \multirow{6}{*}{$\begin{array}{l}\text { Water-soluble carbohydrates } \\
\text { (g/kg DM) }\end{array}$} & Control & $16.5^{\mathrm{a}}$ & $16.3^{\mathrm{a}}$ & $26.8^{b}$ & $15.0^{\mathrm{a}}$ & $12.1^{\mathrm{Aa}}$ & 0.451 & 0.005 & 0.001 & 0.209 \\
\hline & B & 18.3 & 15.7 & 24.2 & 21.1 & $16.6^{\mathrm{AB}}$ & & & & \\
\hline & A & 17.7 & 21.6 & 27.1 & 19.5 & $16.9^{\mathrm{AB}}$ & & & & \\
\hline & $P$ & 19.5 & 22.0 & 28.4 & 26.2 & $21.1^{\mathrm{AB}}$ & & & & \\
\hline & E & $13.5^{a}$ & $16.0^{a}$ & $29.5^{b}$ & $16.7^{a}$ & $18.9^{\mathrm{ABab}}$ & & & & \\
\hline & F & 15.8 & 22.6 & 22.3 & 23.6 & $23.1^{B}$ & & & & \\
\hline \multirow{6}{*}{$\begin{array}{l}\text { Ammonia nitrogen } \\
\text { (g/kg TN) }\end{array}$} & Control & $76.7^{\mathrm{AB}}$ & 70.6 & 68.4 & 69.4 & $63.2^{\mathrm{A}}$ & 1.314 & $<0.001$ & $<0.001$ & 0.017 \\
\hline & B & $81.7^{\mathrm{ABab}}$ & $59.2^{a}$ & $66.6^{a}$ & $53.5^{\mathrm{a}}$ & $99.0^{\mathrm{BCb}}$ & & & & \\
\hline & A & $74.4^{\mathrm{AB}}$ & 72.1 & 72.4 & 84.4 & $99.3^{\mathrm{BC}}$ & & & & \\
\hline & $\mathrm{P}$ & $70.7^{\text {Aab }}$ & $61.4^{a}$ & $58.5^{\mathrm{a}}$ & $61.3^{\mathrm{a}}$ & $76.3^{\mathrm{ABb}}$ & & & & \\
\hline & $E$ & $90.1^{\mathrm{Bbc}}$ & $72.2^{\mathrm{abc}}$ & $66.4^{\mathrm{ab}}$ & $63.8^{a}$ & $95.1^{\mathrm{BCC}}$ & & & & \\
\hline & $\mathrm{F}$ & $85.3^{\mathrm{AB}}$ & 70.9 & 65.8 & 101 & $114^{\mathrm{C}}$ & & & & \\
\hline
\end{tabular}

SEM, standard error of means; DM, dry matter; FW, fresh weight; TN, total nitrogen.

1) B, L. buchneri; A, acetic acid; P, propionic acid; E, 1,2-propanediol; F, 1-propanol.

${ }^{2)} T$, treatment; $D$, ensiling day; $T \times D$, interaction between treatment and ensiling day.

${ }^{A-C}$ Means in the same column with different capital letter differed $(p<0.05)$.

${ }^{a-c}$ Means in the same row with different lowercase differed $(p<0.05)$.

the activities of acetic acid and ethanol-producing microorganisms, such as enterobacteria and yeasts, at early stages of ensiling. $\mathrm{NH}_{3}-\mathrm{N}$ is a sensitive indicator for silage proteolysis and its production is closely related to the $\mathrm{pH}$ decline

Table 8. Changes in microbial composition of fermented total mixed ration during aerobic exposure

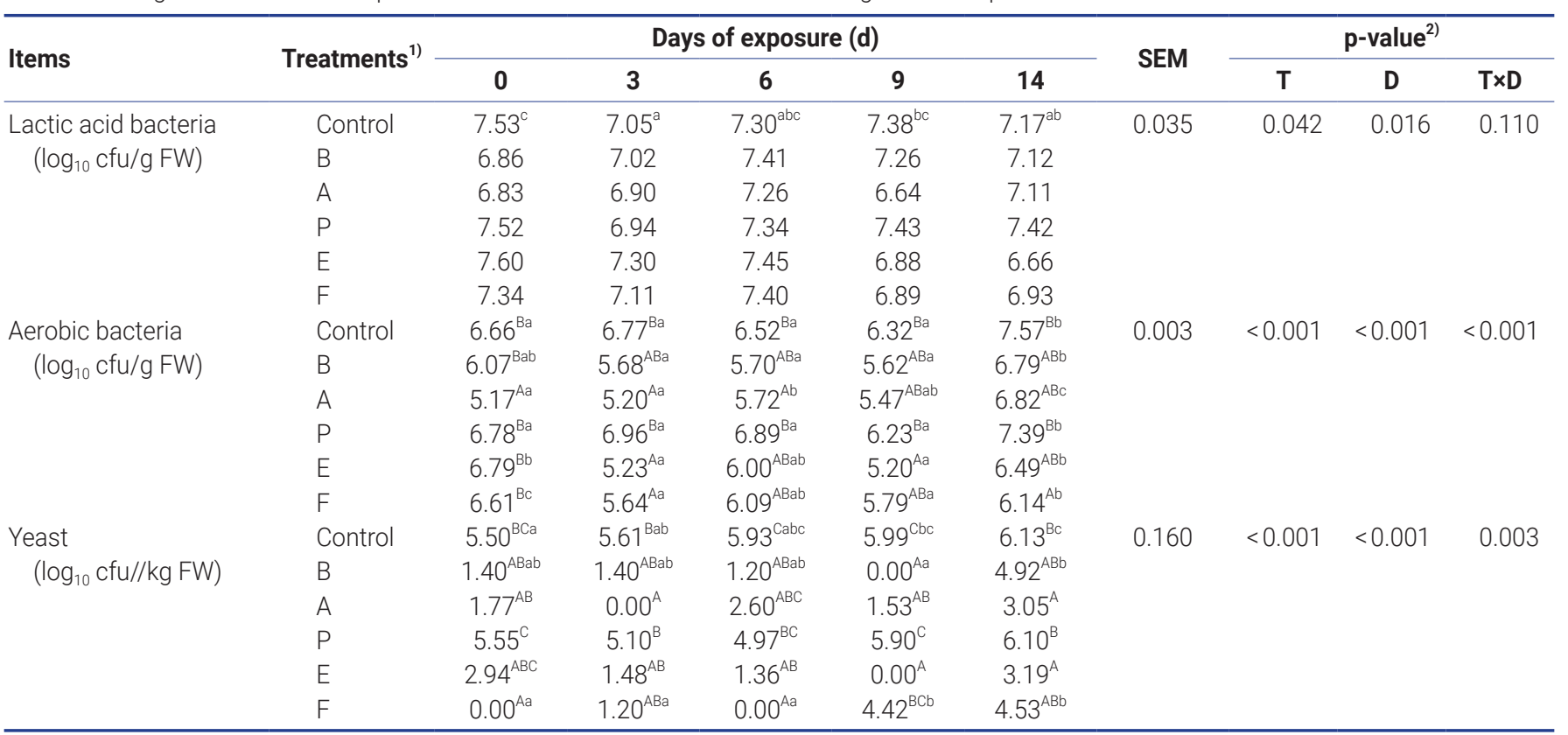

SEM, standard error of means; FW, fresh weight; cfu, colony-forming units.

1) B, L. buchneri; A, acetic acid; P, propionic acid; E, 1,2-propanediol; F, 1-propanol.

2) $T$, treatment; $D$, ensiling day; $T \times D$, interaction between treatment and ensiling day.

${ }^{A-C}$ Means in the same column with different capital letter differed $(p<0.05)$.

${ }^{a-c}$ Means in the same row with different lowercase differed $(p<0.05)$. 
during ensiling [17]. Higher $\mathrm{NH}_{3}-\mathrm{N}$ concentrations demonstrated the slower $\mathrm{pH}$ decline in 1,2-propanediol and 1-propanol-treated TMR in comparison to control.

Krooneman et al [18] previously isolated two strains of $L$. diolivorans from corn silage and demonstrated their abilities of fermenting 1,2-propanediol to propionic acid and 1-propanol. As propionic acid exhibits antimicrobial activity, this fermentative process also contributes to the improvement in aerobic stability of L. buchneri-inoculated silage [4]. In the experiment, adding 1,2-propanediol did not result in increases in propionic acid and 1-propanol concentrations suggesting the absence of $L$. diolivorans in the TMR. In addition, propionic acid addition did not elicit a significant effect on the suppression of aerobic bacteria and yeast when compared with control in this study (Table 3). This might be linked to the presence of microorganism species resistant to low concentrates of propionic acid. Crawshaw et al [19] found some yeasts still flourished in grass silage when treated with propionic acid at a level of 6 litres/t FW (equals to $8 \mathrm{~g} / \mathrm{kg} \mathrm{DM}$ ).

\section{Additives on chemical composition and in vitro degradability}

During ensiling process DM and nutrient losses are unavoidable and mainly results from plant respiration and activities of microorganisms [2]. Addition of 1,2-propanediol and 1-propanediol did not efficiently decline $\mathrm{pH}$ and resulted in lack of preventing microbial activity. This probably caused higher DM loss relative to other treatments (Table 4).

In vitro GP is often used as an important indicator for rumen digestibility potential [11]. In the present study, despite greater DM loss of 1,2-propanediol or 1-propanol treated TMR than others, in vitro digestibility parameters among the silages did not differ, suggesting none of these additives substantially affected ruminal digestion of the TMR.

\section{Additives on aerobic stability}

Aerobic deterioration is initiated, in most cases, by acid-tolerant yeasts [20]. Yeasts can oxidize the fermentation products, leading to $\mathrm{pH}$ rises and proliferation of aerobic microorganisms in air-exposed silage. Aerobic deterioration of silage does not only cause losses of nutritional value, it also negatively affects the safety of silage with an increased risk of pathogenic microorganisms [21]. Well-fermented silages are easily subject to aerobic spoilage when exposed to aerobic condition because of degradation of lactic acid by yeasts and aerobic microbes $[22,23]$. It is generally believed that silages are prone to deteriorate when the yeast population exceeds $5.00 \log _{10}$ cfu/g FW [24]. In the experiment, control began to spoil after 6 days and propionic acid-treated TMR became unstable after 14 days of aerobic exposure (Table 6). This may be linked with high yeast numbers $\left(>5.00 \log _{10} \mathrm{cfu} / \mathrm{g} \mathrm{FW}\right)$ and accumulations of lactic acid $(>72 \mathrm{~g} / \mathrm{kg} \mathrm{DM})$ at the silos opening
(Table 3). The TMRs treated with L. buchneri, acetic acid, 1,2-propanediol, and 1-propanol kept stable throughout the aerobic stability test (Table 6). 1,2-Propanediol itself has no inhibitory effects on yeast growth in silage, and 1-propanol only causes weak inhibition at concentrations of more than $20.0 \mathrm{~g} / \mathrm{kg}$ DM [25]. While acetic acid is well known as an active substance for suppressing the proliferation of yeast, mold and fungi during aerobic exposure. This acid is typically produced in greater quantities than propionic acid during ensiling due to the hetero-fermentative metabolism of LAB [26]. High accumulations of acetic acid in these TMRs may be directly responsible for the increased aerobic stability. Furthermore, ethanol also exhibits antimicrobial activity and reportedly has the ability to potentiate the effect of acetic acid with respect to inhibition of fermenting yeasts [27]. High ethanol concentrations were also supposed to play an important role in preventing aerobic deterioration.

\section{CONCLUSION}

The results of this study showed that treatments of $L$. buchneri, acetic acid, 1,2-propanediol, and 1-propanol did not alter in vitro digestibility, whereas they successfully modulated fermentation patterns towards producing more acetic acid and ethanol and substantially improved the aerobic stability of ensiled TMR. In addition, our findings also suggested that mechanisms of 1,2-propanediol and 1-propanol in altering fermentation may be different from that of L. buchneri or acetic acid. Further study is required to evaluate their effects on metabolic activities and microbial community structures during the ensiling.

\section{CONFLICT OF INTEREST}

We certify that there is no conflict of interest with any financial organization regarding the material discussed in the manuscript.

\section{ACKNOWLEDGMENTS}

This work was financially supported by the Integration and Demonstration of Crop Straw Comprehensive Utilization Technology in Tibet (XZ201901NB07), National Natural Science Foundation of China (Grant No. 32001398), and China Postdoctoral Science Foundation (Grant No. 2020M 671523).

\section{REFERENCES}

1. Kleinschmit DH, Kung L. A meta-analysis of the effects of Lactobacillus buchneri on the fermentation and aerobic stability of corn and grass and small-grain silages. J Dairy 
Sci 2006;89:4005-13. https://doi.org/10.3168/jds.S0022-0302 (06)72444-4

2. Dong Z, Yuan X, Wen A, Desta ST, Shao T. Effects of calcium propionate on the fermentation quality and aerobic stability of alfalfa silage. Asian-Australas J Anim 2017;30:1278-84. https://doi.org/10.5713/ajas.16.0956

3. Li Y, Nishino N. Effects of inoculation of Lactobacillus rhamnosus and Lactobacillus buchneri on fermentation, aerobic stability and microbial communities in whole crop corn silage. Grassl Sci 2011;57:184-91. https://doi.org/10.1111/ j.1744-697X.2011.00226.x

4. Nishino N, Yoshida M, Shiota H, Sakaguchi E. Accumulation of 1,2-propanediol and enhancement of aerobic stability in whole crop maize silage inoculated with Lactobacillus buchneri. J Appl Microbiol 2003;94:800-7. https://doi.org/10.1046/j. 1365-2672.2003.01810.x

5. Auesukaree C, Damnernsawad A, Kruatrachue M, et al. Genome-wide identification of genes involved in tolerance to various environmental stresses in Saccharomyces cerevisiae. J Appl Genet 2009;50:301-10. https://doi.org/10.1007/BF031 95688

6. Carvalho BF, Ávila CLS, Pinto JC, Pereira MN, Schwan RF. Effects of propionic acid and Lactobacillus buchneri (UFLA SIL 72) addition on fermentative and microbiological characteristics of sugar cane silage treated with and without calcium oxide. Grass Forage Sci 2012;67:462-71. https://doi.org/10. 1111/j.1365-2494.2012.00863.x

7. Latimer GW. AOAC International. Official methods of analysis, 21th ed. Gaithersburg, MD, USA: Association of Official Analytical Chemists International; 2019.

8. Van Soest PJ, Robertson JB, Lewis BA. Methods for dietary fiber, neutral detergent fiber, and nonstarch polysaccharides in relation to animal nutrition. J Dairy Sci 1991;74:3583-97. https://doi.org/10.3168/jds.S0022-0302(91)78551-2

9. Broderick GA, Kang JH. Automated simultaneous determination of ammonia and total amino acids in ruminal fluid and in vitro media. J Dairy Sci 1980;63:64-75. https://doi. org/10.3168/jds.S0022-0302(80)82888-8

10.Chen L, Yuan XJ, Li JF, Wang SR, Dong ZH, Shao T. Effect of lactic acid bacteria and propionic acid on conservation characteristics, aerobic stability and in vitro gas production kinetics and digestibility of whole-crop corn based total mixed ration silage. J Integr Agric 2017;16:1592-600. https://doi.org/ 10.1016/S2095-3119(16)61482-X

11.Contreras-Govea FE, Muck RE, Mertens DR, Weimer PJ. Microbial inoculant effects on silage and in vitro ruminal fermentation, and microbial biomass estimation for alfalfa, bmr corn, and corn silages. Anim Feed Sci Technol 2011;163: 2-10. https://doi.org/10.1016/j.anifeedsci.2010.09.015

12.Liu Q, Zhang J, Shi S, Sun Q. The effects of wilting and storage temperatures on the fermentation quality and aerobic stability of stylo silage. Anim Sci J 2011;82:549-53. https://doi.org/10. 1111/j.1740-0929.2011.00873.x

13. Wang Y, Wang C, Zhou W, Yang FY, Chen XY, Zhang Q. Effects of wilting and Lactobacillus plantarum addition on the fermentation quality and microbial community of Moringa oleifera leaf silage. Front Microbiol 2018;9:1817. https://doi. org/10.3389/fmicb.2018.01817

14. McDonald P, Henderson AR, Heron SJE. The biochemistry of silage. 2nd ed. Marlow, UK: Chalcombe Publications; 1991.

15. Ren H, Wang C, Fan W, Zhang B, Li Z, Li D. Effects of formic or acetic acid on the storage quality of mixed air-dried corn stover and cabbage waste, and microbial community analysis. Food Technol Biotechnol 2018;56:71-82. https://doi.org/10. 17113/ftb.56.01.18.5455

16.Mukdsi MCA, Maillard MB, Medina RB, Thierry A. Ethyl butanoate is synthesised both by alcoholysis and esterification by dairy lactobacilli and propionibacteria. LWT 2018;89:3843. https://doi.org/10.1016/j.lwt.2017.10.012

17. Guo X, Zhou H, Yu Z, Zhang Y. Changes in the distribution of nitrogen and plant enzymatic activity during ensilage of lucerne treated with different additives. Grass Forage Sci 2007;62:35-43. https://doi.org/10.1111/j.1365-2494.2007. 00559.x

18. Krooneman J, Faber F, Alderkamp AC, et al. Lactobacillus diolivorans sp. nov., a 1,2-propanediol-degrading bacterium isolated from aerobically stable maize silage. Int J Syst Evol Microbiol 2002;52:639-46. https://doi.org/10.1099/00207 713-52-2-639

19. Crawshaw R, Thorne DM, Llewelyn RH. The effects of formic and propionic acids on the aerobic deterioration of grass silage in laboratory units. J Sci Food Agric 1980;31:685-94. https://doi.org/10.1002/jsfa.2740310712

20.Bernardes TF, De Oliveira IL, Lara MAS, Casagrande DR, Ávila CLS, Pereira OG. Effects of potassium sorbate and sodium benzoate at two application rates on fermentation and aerobic stability of maize silage. Grass Forage Sci 2015; 70:491-8. https://doi.org/10.1111/gfs.12133

21. Bayatkouhsar J, Tahmasbi AM, Naserian AA. Effects of microbial inoculant on composition, aerobic stability, in situ ruminal degradability and in vitro gas production of corn silage. Int J Agrisci 2012;2:774-86.

22. Nishino N, Touno E. Ensiling characteristics and aerobic stability of direct-cut and wilted grass silages inoculated with Lactobacillus casei or Lactobacillus buchneri. J Sci Food Agric 2005;85:1882-8. https://doi.org/10.1002/jsfa.2189

23. Kung L, Ranjit NK. The effect of Lactobacillus buchneri and other additives on the fermentation and aerobic stability of barley silage. J Dairy Sci 2001;84:1149-55. https://doi.org/10. 3168/jds.S0022-0302(01)74575-4

24. Filya I, Sucu E. The effects of lactic acid bacteria on the fermentation, aerobic stability and nutritive value of maize silage. Grass Forage Sci 2010;65:446-55. https://doi.org/10.1111/j. 
1365-2494.2010.00763.X

25.Danner H, Holzer M, Mayrhuber E, Braun R. Acetic acid increases stability of silage under aerobic conditions. Appl Environ Microbiol 2003;69:562-7. https://doi.org/10.1128/ AEM.69.1.562-567.2003

26. Kung L, Shaver RD, Grant RJ, Schmidt RJ. Silage review: interpretation of chemical, microbial, and organoleptic components of silages. J Dairy Sci 2018;101:4020-33. https:// doi.org/10.3168/jds.2017-13909

27. Pampulha ME, Loureiro-Dias MC. Combined effect of acetic acid, $\mathrm{pH}$ and ethanol on intracellular $\mathrm{pH}$ of fermenting yeast. Appl Microbiol Biotechnol 1989;31:547-50. https://doi.org/ 10.1007/BF00270792 